Original Article

\title{
Major threats and habitat use status of Demoiselle crane (Anthropoides virgo), in district Bannu, Pakistan
}

\author{
Principais ameaças e estado de uso de habitat de Demoiselle crane \\ (Anthropoides virgo), no distrito de Bannu, Paquistão
}

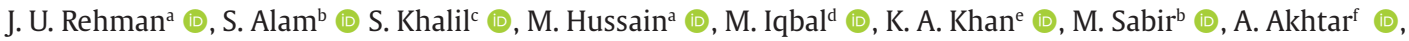 \\ G. Raza' (D, A. Hussain ${ }^{a}$ (D) and U. Habibaa* (D)
}

aThe University of Haripur, Faculty of Basic and Applied Science, Department of Forestry and Wildlife Management, Haripur, Pakistan ${ }^{\mathrm{b} T}$ The University of Haripur, Faculty of Basic and Applied Science, Department of Microbiology, Haripur, Pakistan 'The Islamia University Bahawalpur, Department of Forestry Range and Wildlife Management, Bahawalpur, Pakistan dThe University of Agriculture Peshawar, Department of Agricultural Chemistry and Biochemistry, Peshawar, Pakistan eShandong Normal University, College of Life Sciences, Jinan, China

'The University of Haripur, Department of Psychology, Haripur, Pakistan

gUniversity of Baltistan, Department of Biological Sciences, Skardu, Pakistan

\begin{abstract}
Cranes are the large and attractive Creatures of nature with long necks, legs, and life-span. Adults of both sexes are the same with similar color patterns. Demoiselle cranes spend most of their lifespan on dry grasses. They are also found around the stream, rivers, shallow lakes, natural wetlands, and depressions. To evaluate the current status of habitat use and major threats a study was conducted in tehsil Domel district Bannu. Line transect method and water quality tests (temperature, $\mathrm{PH}$, contamination of E-coli bacteria) were used. To determine the major threats questionnaire method was used. The whole data was analyzed by using SPSS 21 version. Based on the distribution four study sites were selected and four water samples from each study site were taken. Most sites were moderate to highly degraded except Kashoo and kurram river mixing point which was low degraded with livestock grazing and human activities. Water quality tests showed PH ranges from 7-9, temperature 6.5-8.5, and contamination of E-coli in all samples. The social survey revealed that hunting, habitat degradation, and pollution as major threats. Effective long-term conservation and management in the study area are needed to focus on the protection of disturbance-free habitat.
\end{abstract}

Keywords: habitat use, status, Demoiselle crane, Bannu, threats to cranes.

\begin{abstract}
Resumo
Guindastes são a grande e atraente criatura da natureza com um pescoço longo, pernas e vida útil. Adultos de ambos os sexos são os mesmos com padrões de cores semelhantes. Guindastes Demoiselle passam a maior parte da vida em gramíneas secas. Também se encontram ao redor do córrego, rios, lagos rasos, pântanos naturais e depressões. Para avaliar o estado atual do uso do hábitat e as principais ameaças, um estudo foi realizado no distrito de Tehsil Domel, em Bannu. Foram utilizados o método transect e testes de qualidade da água (temperatura, pH, contaminação da bactéria E. coli). Para determinar as principais ameaçasfoi utilizado o método de questionário. Todos os dados foram analisados por meio da versão SPSS 21. Com base na distribuição, foram selecionados quatro locais de estudo e quatro amostras de água de cada local de estudo. A maioria dos locais estava moderada a altamente degradada, exceto no ponto de encontro dos rios Kashoo e Kurram, que teve baixa degradação com pastagem de gado e atividades humanas. Os testes de qualidade da água mostraram variação de $\mathrm{pH}$ de 7-9, temperatura 6,5-8,5 e contaminação de $E$. coli em todas as amostras. A pesquisa do questionário revelou que a caça, a degradação do hábitat e a poluição são as principais ameaças. Efetiva conservação e gestão a longo prazo na área de estudo são necessárias para se concentrar na proteção de um hábitat livre de distúrbios.
\end{abstract}

Palavras-chave: uso de hábitat, status, guindaste Demoiselle, Bannu, ameaças a guindastes.

*E-mail: ume.habiba8@uoh.edu.pk

Received: August 24, 2020 - Accepted: November 19, 2020 


\section{Introduction}

Cranes are large and attractive Creatures of nature with long necks, legs, and life-span. It is a group of birds that can lift the human spirit as a few other wild animals can do (Landfried, 1991). A total of fifteen crane species are found around the world (Harris and Mirande, 2013) while no crane species are found around the continents of Antarctica and South America due to harsh and non-suitable climatic conditions (Baral, 2009). They spend most of their time on the ground in wetland and agricultural fields for feeding purposes (Allen et al., 2006). Crane species includes Sarus crane (Grus Antigone), Brogla crane (Grus rubicunda), Demoiselle crane (Anthropoides virgo), Whooping crane (Grus americana), Sandhill crane (Grus canadensis), Blue crane (Anthropoides paradiseus), Black-crowned crane (Balearica pavonina), Eurasian crane (Grus grus), Siberian crane (Grus leucogeranus), Grey-crowned crane (Balearica regulorum), wattled crane (Bugeranus carunculatus), White-naped crane (Grus vipio), Red-crowned crane (Grus japonensis), Black-necked crane (Grus nigricollis) and Hooded crane (Grus monacha) (Ali and khan, 2007).

Two cranes are passage migrants including the Common crane (Grus grus) and Demoiselle crane (Anthropoides virgo) while one of the black-necked crane (Grus nigricollis) is nomadic. One of a crane is the world highest-flying bird that can fly up to $(1.76 \mathrm{~m})$ named as Sarus crane (Antigone antigone) only found in Nepal (Baral, 2009) also found in the Indian subcontinent including South-East Asia and Australia (Archibald et al., 2003; Harris and Mirande, 2013).

Four species of crane are recorded in Pakistan Demoiselle crane (Anthropoides virgo), Sarus crane (Grus antigone), Siberian crane (Grus leucogeranus), and Eurasian crane (Grus grus) (Mahmood et al., 2011).

The Indus flyway zone including seven big flyways present around the world birds used to migrate during harsh weather conditions passed through Pakistan. The significant migratory birds in Pakistan are cranes, waders, flamingos, geese, ducks, and falcons. These birds used the Hindu Kush, Suleiman ranges, and Karakorum Mountains to reach Pakistan (Ali and Khan, 2007).

Demoiselle crane inhabits hilly steppes that penetrate mountains along wide river valleys, where it may even occupy forest edge habitats such as meadows. It prefers dry areas dominated by wormwood (Artemisia) and grassy steppes of feather grass (Stipa) and fescue (Festuca). It occurs in shrubby Steppes and semi-deserts but occupies damp marshes and swamps only during feeding. Access to water is an essential requirement, and the birds use such diverse sources as rivers, streams, or even wells to drink. They will at times be found on unvegetated alkali flats or large expanses of rock or gravel. Foraging is often done in cultivated areas, especially after the young are well grown. In recent years, nesting in cultivated areas of the united socialist soviet republics has become more prevalent and may be an important conservation development (Kozlova, 1975).

The grassland lies in proximity to the stream, river, and wetlands are the preferred habitat of the Demoiselle cranes for the breeding and wintering ranges (Archibald et al.,
2013). The damp marshes, swamps, and cultivated areas are the main forage places of Demoiselle cranes, while dry grassy land is the preferred breeding grounds (Johnsgard, 1983). During March and April, they return from their winter grounds to the wintering ground, while in the north the breading timing exceeded till the start of June due to temperature fluctuations (Archibald et al., 2013).

In India, the birds occur in winter crop fields, paddy stubble, sandy riverbeds, and on the flat and open margins of lakes and tanks. The easternmost regular wintering grounds are in Burma (coastal and the Irrawaddy Valley); no wintering is supposed to happen in China. In their wintering grounds in India, large flocks gather in cultivated areas, where they consume large amounts of wheat, chickpeas, and alfalfa. Ripening cereal crops are also favored, and the birds sometimes do considerable damage to such crops (Ali and Ripley, 1969).

Demoiselle Crane uses two routes for their migration towards the Indian sub-content; the first one which is mainly used is directly over the Himalayas and the other travelers around the Hindu Kush mountains. In the Himalayas route, they follow the Naurzum wetlands (Kazakhstan), Amu Darya River (Turkmenistan), Lake Ab-i-Estada (Afghanistan), and the juncture region of the Kurram River and the Indus River (Pakistan) for their migration. In India, they are known to winter at Keoladeo National Park. There are many barriers encountered by Demoiselle cranes during this migration including the scarcity of food, unfavorable climatic conditions, and predators (Leito and Ojaste, 2016).

The world's total estimated population of the Demoiselle crane is more than 520,000 (Meine and Archibald, 1996). Due to lack of food, water, shelter, and rain Demoiselle crane migrates on a seasonal basis. 4000 Eurasian and about 8000 Demoiselle cranes migrate every year at Lakki marawat, Bunnu as well as adjacent tribal areas (Ali and Khan, 2007). According to Ahmad and Jan (1995), the total crane population uses D.I. Khan-Bannu-Parachinar route and Zhob too could be 35000-50000 in the spring season. In the district, Chaghi game staff observed about 20,000 cranes enter Baluchistan and fly towards the east every year. Perveen and Khan (2010) concluded that about 7,000 cranes passed through Lakki and Bannu Districts of Khyber Pakhtunkhwa in fall 2008 and spring 2009.

The loss of habitat due to agricultural practices (the conversion of grasslands into agricultural fields) (Archibald et al. 2013), changes in agricultural practices (use of modern machines for processing and harvesting of crops) (Meine and Archibald, 1996), and use of pesticides and herbicides are main threats to the Demoiselle cranes worldwide (Archibald et al. 2013). Similarly, the increasing human population, illegal hunting and trade, urbanization (constriction for enhancing tourism in wetlands), and intentional poisoning (for reducing crop-damaging) are also the major threats to the conservation of Demoiselle cranes. These threats to Demoiselle cranes were increasing throughout its geographic range due to a lack of effective approaches for its conservation (Perveen, 2012). The illegal trade of birds is a major cause of the decline of birds worldwide (Kumar et al. 2002). The price of illegal trade of wild animals and their byproducts is projected 
to $\$ 12$ billion annually (Oldfield, 2002). The demands of wild animals and their byproducts were increasing with time (Freese and Trauger, 2000; Hillstrom and Hillstrom, 2003; Thapar, 2003).

Demoiselle cranes are facing a large number of threats in the form of illegal trades, loss of habitat and hunting and capturing of the birds, etc. The conservation and management of the Demoiselle cranes are very important for the survival of this beautiful creature with help of the community. This study will highlight habitat use status and anthropogenic threats to the Demoiselle crane in the study area, which is more beneficial for developing the conservational and management strategies for the Demoiselle crane.

\section{Materials and Methods}

\subsection{Study area}

The present study was conducted in district Bannu, Khyber Pakhtunkhwa, Pakistan, located in Division Bannu, on the southern side of Peshawar, while its northern side is linked with the tribal areas (FATA) and the district Karak is situated on the eastern part of Bannu (see Figure 1). The district Bannu has located about $190 \mathrm{~km}$ from the capital of KP, Peshawar. The city of district Bannu is situated at $32^{\circ}$ $16 \mathrm{~N}$ and $33^{\circ} 5 \mathrm{~N}$ between the $70^{\circ} 23 \mathrm{E}$ and $71^{\circ} 16 \mathrm{E}$ Similarly, the elevation of Bannu from sea level is $371 \mathrm{~m}$. The total area of district Bannu is 1,227 Sq. KM. This district was further divided into 3 tehsils and 111 union councils. The total human population of Bannu was 1,167892. District
Bannu falls in between the Indus flyway of the migratory birds and a large number of migratory birds including the Demoiselle crane uses this area for winter breeding and feeding ground, as well as the main route for their migration (Mahmood et al., 2011).

\subsection{Data collection}

A Reconnaissance Survey of the study area i.e. Tehsil Domel District Bannu was conducted to identify potential habitat areas of the Demoiselle crane where four study sites were selected for further data collection. Surveys were conducted in the study area on foot for direct observations in the early morning and daytime, using high magnification spotting scopes and binoculars. Study sites were selected depending on the extent of the distribution range of the Demoiselle crane. For this purpose information was also collected from wildlife employees and local people about its potential distribution sites. The presence was confirmed by direct observation of the Demoiselle cranes or indirect pieces of evidence (feathers, calls, and footprints). Elevation and coordinates of cranes occurrence sites were noted.

The line transect method was used to count the number of species while walking along the transect line in each study area. Three transects were marked in each study site of the crane. GPS was used for all transects length measurements.

\subsection{Water quality tests and procedure}

From each study site, four water samples were taken to check the water quality of the habitat. These samples were collected randomly with well field labels like collector

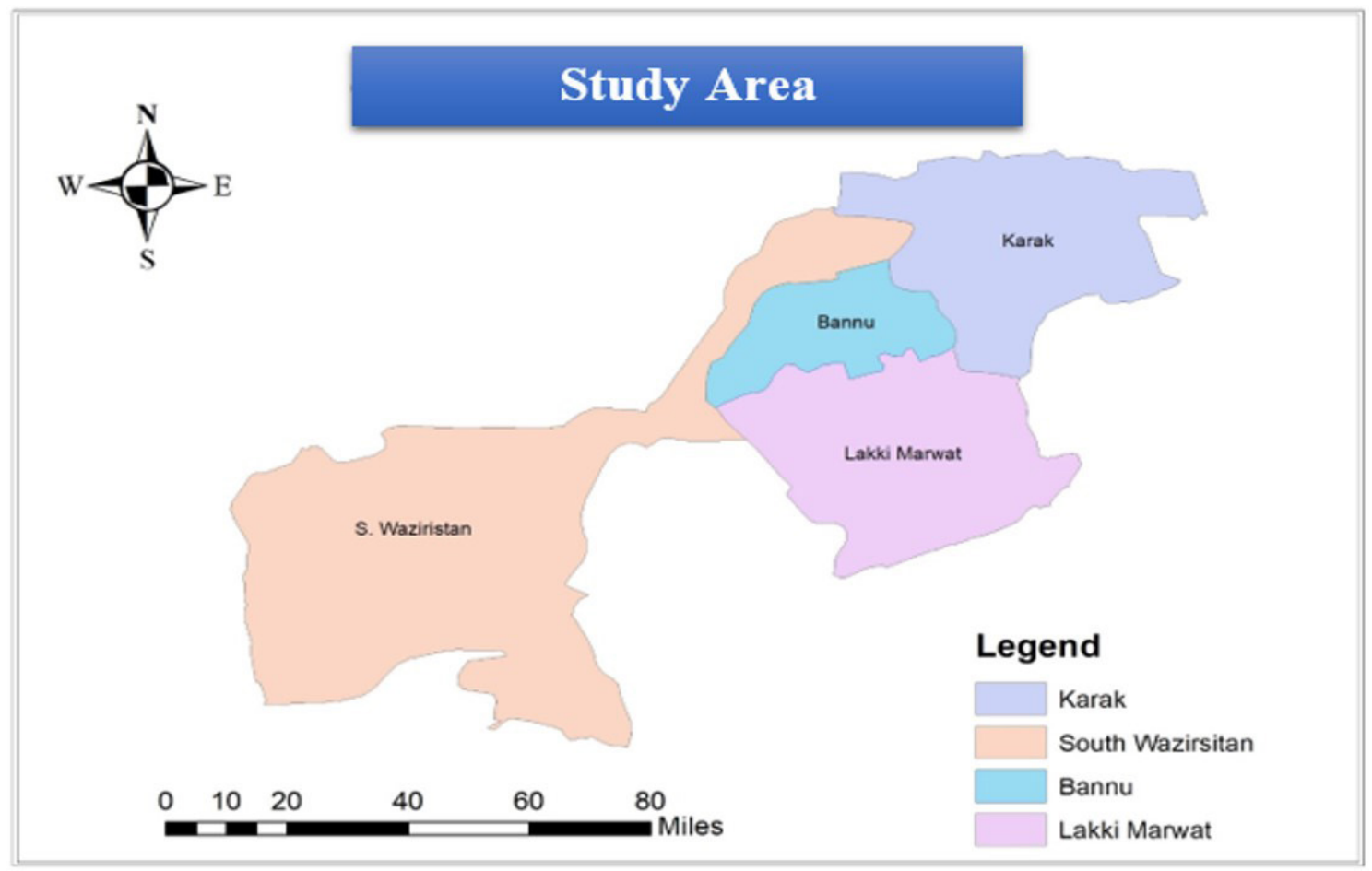

Figure 1. Map of the study area. 
name, date, place, GPS coordinates, and area and brought to the forestry lab, The University of Haripur, Haripur.

Glass, patridecous plates, and media were kept in the Autoclave machine at $121^{\circ} \mathrm{C}$ for 20 minutes. They work combine with pressure, steam, and time. To exterminate spores and microorganisms autoclaves run at high temperatures. It is also used to purify instruments, labware, and sterilize media.

\subsection{Culturing of water samples on media}

Placing $1 \mathrm{ml}$ of water from a sample and used patridicous plates with $9 \mathrm{ml}$ of distilled water named as 10-1 in such a way we took 6 patridicous plates along with $9 \mathrm{ml}$ of distilled water and named as 10-2, 10-3......10-6 while repeating the same process we put $1 \mathrm{ml}$ water from 10-1 to 10-2 and continued this process up to 10-6. This process was continued in the Biosafety cabinet to avoid microbial attacks. We took $1 \mathrm{ml}$ of media from the 6 patridicous plates and spread on plate count agar for the determination of E.Coli bacteria. $1 \mathrm{ml}$ of media was taken from patridicous plate $10-1$ and spread on plate count agar $10-1$, the process was continued up to PCA 106. Six PCA plates were placed in the incubator for 24 hours at $370 \mathrm{C}$.

The culturing on EMB AGAR was the incubated flasks with TSA media which were kept at $370^{\circ} \mathrm{C}$ for 24 hours and 48 hours. Now those plates having no gas or bubbles were taken and spread on EMB Agar for culturing and kept again in the incubator for 24 and 48 hrs. After that, all plates were checked from which it was cleared that E.coli bacteria were found on each plate. E.coli bacteria was found in the large intestine of birds and animals and transferred to their body through water on which these animals or birds feed.

\subsection{Major threats to demoiselle crane in Bannu}

In the study area, a social survey was carried out to collect information on several features of the socio-economic structure of the local community, employees of the Forest and Wildlife Department comprising land-use practices, profession, and their major economic activities. Also, data on illegal hunting, poaching, and agriculture practices were collected from local inhabitants. 100 questionnaires were filled to get a different opinion on major threats to the Demoiselle crane in Bannu. 80\% of questionnaires were filled by the local community (active hunters) while $20 \%$ of questionnaires were filled by Wildlife staff and officials to check ongoing conservation and management practices.

\subsection{Statistical analysis}

All the data was tabulated in SPSS Software 21 version. The relationship between Demoiselle crane densities with each habitat site was determined by Correlation.

\section{Results and Discussion}

To evaluate the current status of the Demoiselle crane habitat, twenty field visits were conducted in the potential habitat areas of Demoiselle cranes. Four study sites were selected (as shown in Table 1). Two crane species, the Common and Demoiselle Crane migrate to Pakistan from Siberia. Hunters in Kurram valley used cranes as a decoy for the attraction and capturing of wild cranes. These captive cranes were trained in such a way that they produced a call when the owner showed a signal to call.

Characteristics of each selected site are given as follows.

\subsection{Kashoo river wetland}

Kashoo River was usually a smooth and plane area with shrubby vegetation. The vegetation included herbs, shrubs, and small grasses. Datora abla was a type of herbs with a dominant feature on the site. Plants included Acacia nilotica, Zizyphus mauritiana, and Delbegia sisso with dominant features. Sarwar et al. (2013) reported the same types of plants in their study in District Bannu.

The soil was sandy with a coarse grain structure. The disturbance was caused by the overgrazing of livestock in the habitat. The local people were greatly dependent upon livestock so they grazed their animals in the surrounding area. Cranes population was recorded as low at this site. Other human activities include camping for animals, bird hunting, and water pollution was also noted. Similar results were documented by (Khan and Pervaiz, 2001) that over-gazing and anthropogenic activities degraded Demoiselle's habitat and reduced the crane population.

\subsection{Kashoo River tributaries}

This habitat type was mostly semi sandy and Ziziphus species were observed most occurred. Here the vegetation observed was mostly bushy (desert palm bush) and shrubby. Cedrela toona, Acacia modesta plants were also found.

Table 1. Characteristics of selected study sites.

\begin{tabular}{|c|c|c|c|c|}
\hline Serial no & Study sites & Location & Disturbance & Area of transects \\
\hline \multirow[t]{2}{*}{1} & Kashoo River wetland & $32.9760 \mathrm{~N}$ & Highly degraded & $1000 \mathrm{~m}^{2}$ \\
\hline & & $70.8480 \mathrm{E}$ & & \\
\hline \multirow[t]{2}{*}{2} & Kashoo River tributaries & $32.9534 \mathrm{~N}$ & Moderately degraded & $1000 \mathrm{~m}^{2}$ \\
\hline & & $70.8370 \mathrm{E}$ & & \\
\hline \multirow[t]{2}{*}{3} & Kashoo \& kurram River mixing point & $32.5515 \mathrm{~N}$ & Low degradation & $1000 \mathrm{~m}^{2}$ \\
\hline & & $70.4635 \mathrm{E}$ & & \\
\hline \multirow[t]{2}{*}{4} & Kurram River & $33.2105 \mathrm{~N}$ & Moderately degraded & $1000 \mathrm{~m}^{2}$ \\
\hline & & $70.7531 \mathrm{E}$ & & \\
\hline
\end{tabular}


Desert needlegrass (Stipa speciosa) was the dominant grass found here. The soil was loamy and the population of cranes was moderate. High overgrazing of the livestock seemed a major threat to the habitat with other human activities including camping, jeep, and bike racing in the desert. The results of Horwich (2001) in Demoiselle were found the same as the present study.

\subsection{Kashoo E' Kurram River mixing point}

It was observed that here the habitat of the crane was mostly deserted with the semi-arid feature. The soil feature was mostly muddy and clay and the habitat with low disturbance. The number of cranes was high in the migration season. Livestock grazing and other human activities are less as compared to other sites. Vegetation includes fountain grass (Datura alba) and typha species are the most dominant herb species of the site. While contrasting results were found by Liu et al. (2003) that soil is loamy, and the population of cranes was moderate. The main threats to the habitat were severe overgrazing and other human activities including camping for hunting in crane habitats.

\subsection{Kurram River}

Kurram River was mostly desert grassland and semi sandy. The water was in running form and Ziziphus species were observed at this site. Desert needlegrass (Stipa speciosa) was the dominant grass and Trifolium alexandrium, Brassica campestris, Spinacea oleracea, Cicer arietinum were also found here. This site was moderately degraded with livestock grazing and human activities. Roberts and Landfried (1987) recorded livestock grazing and other human activities as major threats to crane habitat and population.

\subsection{Water quality determination}

Normal water quality needed for aquatic birds for normal growth and feeding is mean air temperature $\left(10-42{ }^{\circ} \mathrm{C}\right)$, water temperature $\left(9-39^{\circ} \mathrm{C}\right), \mathrm{pH}(6-9)$, electric conduction (160-1600 uS/cm), and dissolved oxygen (1-16 $\left.\mathrm{mg} \mathrm{L}^{-1}\right)$ Ahmed et al. (2016).

To evaluate the water quality of the crane habitat four samples of water, one from each study site were collected and transported to the Microbiology lab at the University of Haripur for testation. We checked three aspects of the samples i.e. PH, temperature, and contamination of E-coli.

$\mathrm{PH}$ of the samples greater than 7 was considered as basic and less than it as acid water was contaminated as E.coli was present in all of the water samples (as shown in Table 2). From the determination of water quality, it was cleared that the water had E.coli bacteria which causes disease in the large intestine of the animals and birds on which they feed.

\subsection{Social survey}

A social survey was conducted for the determination of threats to Demoiselle cranes. 100 Questionnaire s' was filled in which eighty were filled by the local community (crane hunters) and twenty were filled from the wildlife department. Questions were asked from people at hunting places (Azim kala, Domel, Surrani) where they gathered each year to hunt cranes (as shown in Table 3).

\subsection{Threats to the population of Demoiselle crane}

A social survey of this study showed that the number of Demoiselle cranes had decreased and community hunt for different purposes e.g. Domestic use, sports hunting, and fun (as shown in Table 4).

The results of this study showed that hunting is a serious and major threat to the population of Demoiselle crane in the study area. Most of the people used guns for hunting for

Table 2. Water quality test.

\begin{tabular}{|c|c|c|c|c|}
\hline Study sites & $\begin{array}{l}\text { Sample } \\
\text { Names }\end{array}$ & $\begin{array}{l}\text { PH of water collected from the } \\
\text { different sites of the study area }\end{array}$ & Temperature & E. coli \\
\hline \multirow[t]{4}{*}{ Kashoo River wetland } & S-1 & 7.5 & $7.8^{\circ} \mathrm{C}$ & Present \\
\hline & $\mathrm{S}-2$ & 8.2 & $9^{\circ} \mathrm{C}$ & Present \\
\hline & $\mathrm{S}-3$ & 8.5 & $8.5^{\circ} \mathrm{C}$ & Present \\
\hline & $\mathrm{S}-4$ & 7.9 & $7.5^{\circ} \mathrm{C}$ & Present \\
\hline \multirow[t]{4}{*}{ Kashoo River tributaries } & $\mathrm{S}-1$ & 7.2 & $6.5^{\circ} \mathrm{C}$ & Present \\
\hline & $\mathrm{S}-2$ & 8.4 & $6.9^{\circ} \mathrm{C}$ & Present \\
\hline & S-3 & 9.3 & $7.7^{\circ} \mathrm{C}$ & Present \\
\hline & S-4 & 7.9 & $8.5^{\circ} \mathrm{C}$ & Present \\
\hline \multirow[t]{4}{*}{ Kashoo \& Kurram River mixing point } & S-1 & 7.6 & $7.8^{\circ} \mathrm{C}$ & Present \\
\hline & $\mathrm{S}-2$ & 9 & $7.9^{\circ} \mathrm{C}$ & Present \\
\hline & $\mathrm{S}-3$ & 8.8 & $8^{\circ} \mathrm{C}$ & Present \\
\hline & $\mathrm{S}-4$ & 9.4 & $8.3^{\circ} \mathrm{C}$ & Present \\
\hline \multirow[t]{4}{*}{ Kurram River } & S-1 & 7.9 & $8.5^{\circ} \mathrm{C}$ & Present \\
\hline & $\mathrm{S}-2$ & 7.6 & $7.8^{\circ} \mathrm{C}$ & Present \\
\hline & $\mathrm{S}-3$ & 9 & $7.9^{\circ}$ & Present \\
\hline & $\mathrm{S}-4$ & 7.8 & $10.7^{\circ} \mathrm{C}$ & Present \\
\hline
\end{tabular}


Table 3. Socio-demographic profile of respondents.

\begin{tabular}{lcc}
\hline \multicolumn{1}{c}{ Characteristics } & Frequency & Valid Percent \\
\hline Number of respondents & 74 & 47.4 \\
Azim kala & 20 & 40.2 \\
Domel & 6 & 12.4 \\
Surrani & & \\
Age & 2 & 1.0 \\
$25-35$ & 62 & 62.6 \\
$36-45$ & 36 & 36.4 \\
$46-55$ & & \\
Occupation & 19 & 19.2 \\
Student & 1 & 1.0 \\
Forest and Wildlife & & \\
Department & 79 & 79.8 \\
Crane Keepers &
\end{tabular}

Table 4. Status of population and habitat of Demoiselle crane in the study area.

\begin{tabular}{|c|c|c|}
\hline Question asked & Frequency & Valid percent \\
\hline \multicolumn{3}{|c|}{$\begin{array}{l}\text { Is the number of Demoiselle cranes is increasing or } \\
\text { Decreasing? }\end{array}$} \\
\hline Increasing & 37 & 37.4 \\
\hline Decreasing & 61 & 61.6 \\
\hline \multicolumn{3}{|c|}{ Why people hunt cranes? } \\
\hline Domestic Use & 55 & 55.6 \\
\hline Poaching Activities & 18 & 18.2 \\
\hline Game & 25 & 25.3 \\
\hline \multicolumn{3}{|c|}{ Where most people hunt cranes? } \\
\hline Kashoo River & 49 & 49 \\
\hline Kurram River & 51 & 51 \\
\hline \multicolumn{3}{|c|}{ What method of hunting is used for cranes hunting? } \\
\hline By Gun & 69 & 69.7 \\
\hline Any Other & 30 & 30.3 \\
\hline \multicolumn{3}{|c|}{$\begin{array}{l}\text { Whether the habitat of demoiselle cranes is increasing or } \\
\text { decreasing? }\end{array}$} \\
\hline Increasing & 40 & 40.4 \\
\hline Decreasing & 59 & 59.6 \\
\hline
\end{tabular}

sports and hunting did not raise the standard of the local community. The same results were reported by Perveen (2012) concluded that hunting cranes are more fun than anything else in District Bannu. During hunting season proper camps were established near the resting grounds of the crane species. Most of the traditional hunters from the whole district came there and hunt cranes. Similar activities are reported by another study in Lakki Marwat and Bannu (Khan, 1990; Farooq, 1992). It is alarming that the crane population was continuously decreasing due to no effective conservation and hunting plans.

The habitat of the Demoiselle crane is shrinking rapidly because the water was diverted to different directions for different purposes. More and more people from surrounding villages approach the habitat for hunting so degradation by establishing hunting camps was in full swing. According to the study degradation rate of the habitat of cranes in district Karak was very high, which was also reported by another study that the Siberian crane was no more observed in Pakistan since the late nineteen eighty (UNEP, 1995).

It was observed during this study that most of the migratory crane species crossed through Kashoo and Kurram River. Farooq et al. (1993) also noticed that many crane species are observed around Kurram and Kashoo River. According to this study, another important threat to the Demoiselle crane was pollution in Kurram and Kashoo River. Another study showed that the environment of cranes and their routes are highly polluted by domestic and industrial untreated sewage (Tariq and Aziz, 2015).

According to the respondents, migratory flocks of cranes decrease $95 \%$ in the last $15-20$ years. During the migration periods rarely 5-9 flocks passed through this route. The number of individuals in each flock was not greater than 5-11. While in past the flocks' number was more than 30-50 in each flock. A similar study was reported that due to the degradation of watershed areas, which serve as a habitat for crane species, its population declined in recent years Liu et al. (2003).

\section{Conclusion}

Demoiselle crane is one of the important migratory birds, visit different areas of Pakistan including the Bannu (KP). These areas are acting as winter breeding and feeding grounds of the Demoiselle crane. But currently, it is suffering from different illegal hunting, capturing, and anthropogenic activities. The captivity and hunting of Demoiselle cranes were more common and hunters have 2 to 10 in their captivity, while $87 \%$ of the hunter were reported as regular hunters. Most of the hunting camps were placed near ( $<500$ meters) water bodies and each hunting camp contained hunting permits issued by the Khyber Pakhtunkhwa wildlife department. The number of Demoiselle cranes in each flock varies and about (78\%) flocks have 1-10 birds. The hunting of Demoiselle crane does not have any significant impact on the social livelihood of the local community, because most of the hunter hunts the Demoiselle crane for recreation and family honor.

These threats are the major hurdles in the success of conservational strategies. The present study was designed to achieve the following objectives which are more beneficial for the conservation of the Demoiselle crane in district Bannu (KP). To overcome these issues and increases the success of conservational strategies for Demoiselle crane, improvement of habitat, reduction in anthropogenic activities, and illegal hunting and smuggling of Demoiselle crane are recommended. Awareness at the community level about the role of the Demoiselle crane for a healthy and balanced ecosystem is recommended. 


\section{References}

AHMAD, A. and JAN, A., 1995. Crane research and protection in Europe. Halle-Wittenberg: Martin-Luther Universität, pp. 337-352.

AHMED, M., VICTOR, R., JASHOUL, M. and CHOUDRI, B.S., 2016. utilization of low quality water of mountain reservoirs: a case study from Al Jabal Al Akhdar, Oman. Journal of Mountain Science, vol.45, no. 8, pp. 1423-1430. http://dx.doi.org/10.1007/ s11629-015-3748-7.

ALI, S. and RIPLEY, D., 1969. Handbook of the birds of India and Pakistan. London: Oxford University Press, vol. 2.

ALI, Z. and KHAN, A., 2007. Captive breeding and multiple clutching techniques of captive cranes in Bannu and Lakki Marwat, NWFP. Bannu: The minisitry of environment's Pakistan wetlands programme, pp . 42.

ALLEN, D., ESPAÑOLA, C., BROAD, G., OLIVEROS, C. and GONZALES, J.C.T., 2006. New bird records for the Babuyan islands, Philippines, including two first records for the Philippines. Forktail, vol. 22, pp. 57-70.

ARCHIBALD, G.W., MEINE, C.D. and GARCIA, E.F.J., 2013 [viewed 6 March 2015]. Demoiselle Crane (Anthropoides virgo). In: J. DEL HOYO, A. ELLIOTT, J. SARGATAL, D.A. CHRISTIE and E. DE JUANA, eds. Hand book of the birds of the world alive [online]. Barcelona: Lynx Edicions. Available from: http://www.hbw. com/node/53552

ARCHIBALD, G.W., SUNDAR, K.G. and BARZEN, J., 2003. A review of the three subspecies of Sarus Cranes Grus antigone. Journal of Ecological Society, vol. 16, pp. 5-15.

BARAL, H.S., 2009. Protected birds of Nepal: a review of their status, distribution and habitat. The Initiation, vol. 3, pp. 66-80. http:// dx.doi.org/10.3126/init.v3i0.2429.

FAROOQ M., 1992. Crane migration through Dera Ismail Khan (NWFP): Conservation problems and prospects. Peshawar, Pakistan: Pakistan Forest Institute. pp. 1-135

FAROOQ M., AHMAD, A. and GHALIB, S.A., 1993. The cranes of Pakistan. Pakistan: World Wide Fund for Nature, pp. 1-54.

FREESE, C.H. and TRAUGER, D.L., 2000. Wildlife markets and biodiversity conservation in North America. Wildlife Society Bulletin, vol. 28, pp. 42-51.

HARRIS, J. and MIRANDE, C., 2013. A global overview of cranes: status, threats and conservation priorities. Chinese Birds, vol. 4 , no. 3, pp. 189-209. http://dx.doi.org/10.5122/cbirds.2013.0025.

HILLSTROM, K. and HILLSTROM, L.C., 2003. Asia: a continental overview of environmental issues. California, USA: ABC-CLIO.

HORWICH, R.H., 2001. Developing a migratory whooping crane flock. In: D.H. Ellis, ed., Proceedings of the Eighth North American Crane Workshop, 11-14 January 2000, Albuquerque, New Mexico. Seattle, Wash: North American Crane Working Group, pp. 85-95.

JOHNSGARD, P., 1983. Cranes of the world. Bloomington: Indiana University Press, vol. 1983, pp. 24-107.

KHAN, A.A., 1990. The wildlife of Sindh arid zone-variety, threats and potential. Pakistan: IUCN, pp. 1-16. Report prepared for the FMS/AG RODEV. SAZDA.

KHAN, S.R. and PERVAIZ, A.N., 2001. The integration of economic measures into the national biodiversity strategy and action plan of Pakistan. Pakistan: IUCN, p. 7.
KOZLOVA, E.V., 1975. Birds of zonal steppes and deserts of Central Asia. Trudy Zoologicheskogo Instituta Akademii Nauk S.S.S.R., vol. 59, pp. 1-252.

KUMAR, K., LIPSCOMB, J. and MENON, J. 2002. International Business Machines Corp, Personalizing rich media presentations based on user response to the presentation. U.S. Patent US6448980B1, vol. 6, pp. 448,980.

LANDFRIED, S.E., 1991. Western flocks of Siberian cranes at the brink of extinction. Nature, vol. 12, no. 199, pp. 4-6.

LEITO, A. and OJASTE, I., 2016. Monitoring of the Common crane in Estonia, period 2010-2014. In: Proceedings of the VIII European Crane Conference, 2016, Stralsund. Laguna de Gallocanta, Spain: Asociacion Amigos de Gallocanta, pp. 62-68.

LIU, Y., NISHIYAMA, S. and KUSAKA, T., 2003. Examining landscape dynamics at a watershed scale using landsat TM imagery for detection of wintering hooded crane decline in Yashiro, Japan. Environmental Management, vol. 31, no. 3, pp. 365-376. http:// dx.doi.org/10.1007/s00267-002-2785-5. PMid:12592452.

MAHMOOD, T., AMIN, N. and RAIS, M., 2011. Captive breeding of Demoiselle Crane in Lakki Marwat, Khyber Pakhtunkhwa, Pakistan. Беркут, vol. 20, no. 1-2, pp. 153-158.

MEINE, C. and ARCHIBALD, G., eds., 1996. The cranes: status survey and conservation action plan. Switzerland, Gland: IUCN.

OLDFIELD, S., ed., 2002. The trade in wildlife: regulation for conservation. Cambridge, United Kingdom: Fauna and Flora International, Resource Africa and TRAFFIC International.

PERVEEN, F. and KHAN, H.U., 2010. Pressure from hunting on crane species in southern districts of northern Pakistan. Chinese Birds, vol. 1, no. 4, pp. 244-250. http://dx.doi.org/10.5122/ cbirds.2010.0021.

PERVEEN, F., 2012. Biological status of captive crane in southern districts of northern Pakistan. Journal of Life Science, vol. 6, no. 3, pp. 304-311.

ROBERTS, T.J. and LANDFRIED, S.E., 1987. Hunting pressures on cranes migrating through Pakistan. In: Proceedings of the 1983 International Crane Workshop, 1987, Madison, USA. Madison, USA: University of Wisconsin, pp. 139-145.

SARWAR, M., HUSSAIN, I., KHAN, A. and ANWAR, M., 2013. Diet composition of the Demoiselle crane (Anthropoides virgo) migrating through Lakki Marwat, Pakistan. Avian Biology Research, vol. 6, no. 4, pp. 269-274. http://dx.doi.org/10.3184/ $175815513 X 13802893287049$.

TARIQ M. and AZIZ, R., 2015. Threats and hunting methods of crane species in District Karak of Khyber Pakhtunkhwa, Pakistan. Journal of Earth and Environmental Sciences, vol. 5, no. 22, pp. 11-15.

THAPAR, V., 2003. Battling for survival: India's wilderness over two centuries. New Delhi, India: Oxford University Press.

UNITED NATIONS ENVIRONMENT PROGRAMME - UNEP, and CONVENTION ON THE CONSERVATION OF MIGRATORY SPECIES OF WILD ANIMALS - CMS, 1995. Memorandum of understanding concerning conservation measures for the Siberian Crane: report of the first meeting states. Bonn, Germany: Secretariat of the Convention on the Conservation of Migratory Species of Wild Animals, pp. 1-113. 